\title{
Ether-water partitioning and permeability through nude mouse skin in vitro. I. Urea, thiourea, glycerol and glucose
}

\author{
Chrisita Ackermann ${ }^{1}$ and Gordon L. Flynn ${ }^{2}$ \\ ${ }^{\prime}$ Department of Pharmaceutics, Potchefstroom University for Christian Higher Education, Potchefstroom (South Africa) \\ and ${ }^{2}$ College of Pharmacy, University of Michigan, Ann Arbor, MI 48109 (U.S.A.) \\ (Received 20 September 1985) \\ (Modified version received 9 October 1986) \\ (Accepted 7 November 1986)
}

Key words: Urea; Thiourea; Glycerol; Glucose; Skin; Permeability; Ether-water; Partitioning

\begin{abstract}
Summary
The permeability coefficients for urea, thiourea, glycerol and glucose were determined for full thickness nude mouse skin and the dermis of nude mice by means of an infinite dose diffusion cell system in vitro. The permeability coefficients were found to be very low and ranged between $1.0 \times 10^{-4}$ and $1.4 \times 10^{-4} \mathrm{~cm} / \mathrm{h}$ for full thickness skin. The permeability coefficients for the dermis ranged between 0.3 and $0.7 \mathrm{~cm} / \mathrm{h}$. The ether-water partitioning of urea, thiourea, glycerol and glucose was determined by means of a radiotracer method. This simple method proved to be very sensitive to low concentrations and to be economical both in relation to time and reagents. There appears to be no dependence of permeability on the polarity of these compounds when permeability is taken as a function of the ether-water partition coefficient.
\end{abstract}

\section{Introduction}

The assessment of permeability coefficients by in vitro methods with sectioned or full thickness nude mouse skin is well-established and a convenient way of studying the basic principles underlaying percutaneous absorption. If the etherwater partition coefficients can be correlated with the percutaneous absorption of compounds over a wide range of hydrophobicity, it will strengthen the hypothesis that the skin acts as a simple lipoidal barrier. The aim of this study was to assess the validity of such a hypothesis for very

Correspondence: C. Ackermann, Department of Pharmaceutics, Potchefstroom University for Christian Higher Education, Potchefstroom 2520 (South Africa) hydrophilic compounds like urea, thiourea, glycerol and glucose.

The ether-water partition coefficients of urea and thiourea have been determined by Collander (1949), Ross (1951) and Sandell (1966), those of glycerol by Collander (1949) and Ross (1951) and the ether-water partition coefficient of glucose has only been approximated by Ross (1951). These values were determined by means of rather outmoded laborious techniques. It was therefore decided to assess the utility of a very simple radiotracer technique in this regard while simultaneously assessing the validity of the existing ether-water partition coefficients of these compounds.

The work of Treherne (1956) on the relationship between the ether-water partition coefficient and percutaneous absorption of a few polar non- 
electrolytes has been cited much in the literature and was taken as a point of departure for the present investigation. He used radiolabelled ethyl iodide, methanol, ethanol, thiourea, glycerol, urea and glucose in percutaneous absorption studies on rabbit skin in vitro. We found that ethyl iodide was unstable in isotonic sodium chloride solution. Ethyl iodide could therefore not be used in the diffusion cell. Sufficient data on methanol and ethanol already existed. Therefore only urea, thiourea, glycerol and glucose were selected to characterise the percutaneous absorption of hydrophilic compounds. Because nude mouse skin resembles human skin well (Dürrheim et al., 1980), it was assumed that nude mouse skin would be a better model than excised rabbit skin to obtain the correlation between the ether-water partition coefficient and the permeability coefficient.

\section{Materials and methods}

\section{Materials}

The following substances were used in this study:

D- $\left[1,3-{ }^{14} \mathrm{C}\right]$ glucose, supplied as a sterile aqueous solution containing 3\% alcohol;

$\left[1,3-{ }^{14} \mathrm{C}\right] g l y c e r o l$, supplied as a sterile aqueous solution;

$\left[{ }^{14} \mathrm{C}\right]$ thiourea, supplied as a powder and made up in reagent grade ethanol;

and $\left[{ }^{14} \mathrm{C}\right]$ urea, supplied as an ethanol solution.

The radiolabelled glucose and glycerol were obtained from Amersham Corporation and the thiourea and urea from New England Nuclear. Analytical grades of unlabelled urea, glycerol and glucose were also used. All the compounds were used as received with no attempt to confirm or increase the purity. Stock solutions of the unlabelled compounds were freshly made before each experiment. All stock solutions were kept in a refrigerator. The diffusion media were prepared from $0.9 \%$ sodium chloride, henceforth referred to as normal saline.

Double-distilled water and analytical reagent grade ether were used to prepare the cosaturated phases for the partitioning study. For urea, glycerol and glucose $0.01 \mathrm{M}$ of the unlabelled compounds was used on both sides of the skin to saturate the sorptive capacity of the cell system, so that the permeation of the tracer amount of labelled compound could easily be followed. In the case of thiourea, mass balance was obtained without saturation. The following concentrations of the labelled compounds were used in the donor cells: $\left[{ }^{14}\right.$ C]urea $\left(9.2 \times 10^{-6} \mathrm{M}\right),\left[{ }^{14} \mathrm{C}\right]$ thiourea $(2.6 \times$ $\left.10^{-6} \mathrm{M}\right), \quad\left[{ }^{14} \mathrm{C}\right]$ glycerol $\left(5.8 \times 10^{-6} \mathrm{M}\right)$ and $\left[{ }^{14} \mathrm{C}\right]$ glucose $\left(3.3 \times 10^{-6} \mathrm{M}\right)$.

Determination of the ether-water partition coefficients

Water and ether were added to a $120-\mathrm{ml}$ separator and shaken to obtain cosaturation of the phases. The separator was set aside for $24 \mathrm{~h}$ to allow for temperature and further phase equilibrium. All remaining steps were carried out at room temperature $\left(23 \pm 1^{\circ} \mathrm{C}\right)$. Two $\mathrm{ml}$ of the water phase were placed in a scintillation vial by means of a micropipette. The weight of the vial plus the 2 $\mathrm{ml}$ water phase was recorded. An appropriate amount of the ether phase was placed in the vial (2-4 ml). A sample of the radiolabelled material was placed in the vial $(20-50 \mu 1)$ by means of a micropipette. The vial was thoroughly shaken by hand for $2 \mathrm{~min}$ and allowed to stand for 20-30 min to assure complete phase separation.

Because the ether is volatile, the weight of the vial plus contents was recorded just before the samples were taken in order to calculate the volume of the ether phase. The samples from the ether and water phases were taken without disturbing the phase equilibrium. Three samples per phase per vial were taken. The samples were put in $10 \mathrm{ml}$ scintillation cocktail and analysed with a scintillation counter.

\section{Mouse skin membrane preparations}

The abdominal skin from the nude mouse (SKH-hr-1, Skin Cancer Hospital, Temple University, Philadelphia, Pennsylvania) was used exclusively in this study. Male mice older than 90 days were used since studies by Behl and coworkers have shown that the age-related variability of alkanol permeability coefficients could be minimised by using older animals (Smith, 1982).

The mice were killed by severing the spinal 
cord. Four abdominal sections of full thickness skin, each about $1.5 \mathrm{~cm}^{2}$ in area were removed from the mouse by blunt dissection and mounted between the cells of 4 glass diffusion cell systems. During the preparation and execution of each experiment the skin was not stretched or stressed too much during the rinsing and filling of the diffusion cells.

Dermal tissue was obtained in the following manner: full-thickness abdominal hairless mouse skin, mounted in a large diffusion cell system (4.9 $\mathrm{cm}^{2}$ exposed to diffusion medium and $20 \mathrm{ml}$ capacity) was soaked in normal saline at $37^{\circ} \mathrm{C}$ for $12 \mathrm{~h}$. The skin was removed and the epidermis peeled off, using two micropipette tips as tweezers. The dermis was then mounted in a small diffusion cell system $\left(0.7 \mathrm{~cm}^{2}\right.$ exposed to $1.3 \mathrm{ml}$ diffusion medium).

The general experimental procedure has been described by Ackermann (1983), and Ackermann et al. (1985).

\section{Calculation of the permeability coefficients}

The theory underlying the calculation of permeability coefficients has already been thoroughly discussed (Aguiar and Weiner, 1969; Flynn, 1979; Smith, 1982).

Since sink conditions were maintained throughout each experiment, the equation derived from Fick's law could be used for the calculation of the permeability coefficients. The permeability data were plotted as counts (amount of permeant) collected in the receptor compartment as a function of time. Correction was made for sampling, which was done by replacement. The permeability coefficient at different points in a run was calculated from:

$J_{T}=P A \Delta C$

where $J_{T}(\mathrm{cpm} / \mathrm{h})$, is the total flux calculated from the slope of plots of the amount penetrated vs time; $P$ is the permeability coefficient $(\mathrm{cm} / \mathrm{h})$; $A$ is the diffusion area $\left(\mathrm{cm}^{2}\right)$; and $C$ is the concentration differential across the membrane, which was taken to be equal to the donor phase concentration $\left(\mathrm{cpm} / \mathrm{cm}^{3}\right)$. It should be noted that $J_{T}$ is to be differentiated from $J$, the flux per unit area, as used earlier. Samples of $400 \mu 1$ were taken to determine the concentration, $C$. Thus, the permeability coefficient is calculated from:

$P=J_{T} / A \Delta C$

and since $J_{T}=V(\mathrm{~d} C / \mathrm{d} t)$ :

$P=V(\mathrm{~d} C / \mathrm{d} t) / A \Delta C$

where $V$ is the half-cell volume and the volume of the receptor compartment $\left(\mathrm{cm}^{3}\right)$ and $\mathrm{d} C / \mathrm{d} t$ is the steady-state slope in $\mathrm{cpm} / \mathrm{cm}^{3}$.

\section{Results and Discussion}

The $\log$ of the ether-water partition coefficients obtained in this study is listed together with those of other workers in Table 1.

When the ether-water partition coefficients obtained in this study are compared to those of other workers, there seems to be an excellent correlation between the values for thiourea and urea and a fair correlation in the case of glycerol. The ether-water partition coefficient of glucose was only reported by Ross (1951) who gave a maximum value because his analytical methods were not sensitive enough to determine the extremely low concentration of glucose in the ether phase.

The typical permeation profile found with thiourea is presented in Fig. 1. The insert on the

\section{TABLE 1}

Log of ether-water partition coefficients obtained in this study for glucose, urea, glycerol and thiourea and those by other authors

\begin{tabular}{lccl}
\hline Compound & $\begin{array}{l}\text { Log partition } \\
\text { coefficient }\end{array}$ & Compound & $\begin{array}{l}\text { Log partition } \\
\text { coefficient }\end{array}$ \\
\hline Glucose & $-5.06^{\mathrm{a}}$ & Glycerol & $-3.29^{\mathrm{a}}$ \\
& $<-4.00^{\mathrm{b}}$ & & $-2.96^{\mathrm{b}}$ \\
& & & $-3.18^{\mathrm{d}}$ \\
Urea & $-3.49^{\mathrm{a}}$ & Thiourea & $-2.14^{\mathrm{a}}$ \\
& $-3.52^{\mathrm{c}}$ & & $-2.10^{\mathrm{c}}$ \\
& $-3.30^{\mathrm{b}}$ & & $-2.14^{\mathrm{b}}$ \\
& $-3.33^{\mathrm{d}}$ & & $-2.20^{\mathrm{d}}$ \\
\hline
\end{tabular}

a This study. Mean of six determinations; ${ }^{b}$ Ross (1951);

${ }^{c}$ Sandell (1966); ${ }^{d}$ Collander (1949). 


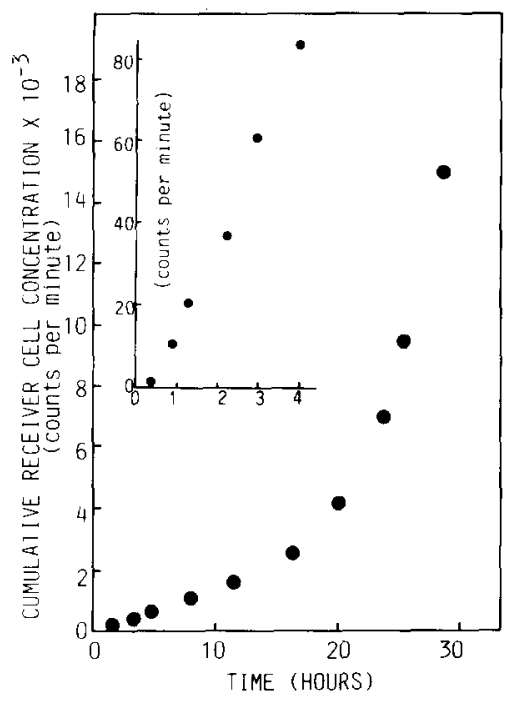

Fig. 1. Cumulative amount of $\left[{ }^{14} \mathrm{C}\right]$ thiourea (cpm) in the receiver cell as a function of time when permeated through full thickness nude mouse skin.

graph represents the detailed profile over the first $4 \mathrm{~h}$. With urea, glycerol and glucose an acceptable, reproducible profile could not be obtained by using only a tracer amount of radio-labelled material in the donor cell. Although a decrease of concentration in the donor cell could be measured, the concentration in the receiver cell did not reflect good mass balance. It was concluded that these compounds were being sorbed and bound or metabolised and bound in the skin or on the surfaces of the diffusion cell.

It was found that by putting a $0.01-\mathrm{M}$ unlabelled solution of the compound in both the receiver and donor cells, the sorptive capacity of the cell system, including the skin, was saturated and the permeation of the radiolabelled compound could easily be followed. After addition of unlabelled solutions of urea, glycerol and glucose, essentially the same permeation profile as obtained with thiourea was observed for these compounds.

It seemed as if a mass balance was almost immediately obtained at the start of the experiment and that the typical lag time phenomenon (Dürrheim et al., 1980; Smith, 1982) was absent in the case of these compounds. Because of the very slow permeation rate of the hydrophilic com- pounds over the first few hours, an extremely slow build-up of radiolabelled compound occurs in the receiver cell. Therefore, a problem existed with the accuracy of experimental data over the first 6-10 $\mathrm{h}$ of an experiment due to the difficulty in detecting the exact concentration of the compound in the receiver cell.

Another way to determine the permeation profile would be to measure the loss from the donor cell instead of the gain in the receiver cell. In this case the concentration in the donor cell has to be much higher than in the receiver cell to provide a sufficient concentration gradient over the skin for the disappearance of a detectable amount of radiolabelled compound (e.g. $100 \mathrm{cpm}$ ). A very small error in sample-taking from the donor, e.g. a $0.25 \%$ error, would represent a difference of 1000 $\mathrm{cpm}$ on $400000 \mathrm{cpm}$. The magnitude of the aforementioned problem is increased by the variation in the counting of the scintillation counter.

The permeability coefficients of urea, thiourea, glycerol and glucose when permeating full thickness skin and the dermis of the nude mouse are presented in Table 2.

A continuously increasing permeation rate as a function of time was encountered with all 4 compounds. This phenomenon was also described for hydrocortisone and a series of hydrocortisone- $n$ alkyl-esters by Smith (1982). It was, however, not previously described for other hydrophilic compounds. The factors responsible for this phenomenon are unknown and need further research.

The permeability coefficients, as calculated over the first $6 \mathrm{~h}$ and last $6 \mathrm{~h}$ of a $30 \mathrm{~h}$ run for each of

\section{TABLE 2}

Permeability coefficients of glucose, urea, glycerol and thiourea for full thickness nude mouse skin (first $6 \mathrm{~h}$ ) and dermis of nude mouse skin

\begin{tabular}{lll}
\hline Compound & $\begin{array}{l}\text { Permeability } \\
\text { coefficient full } \\
\text { thickness }(\mathrm{cm} / \mathrm{h})\end{array}$ & $\begin{array}{l}\text { Permeability } \\
\text { coefficient } \\
\text { dermis }(\mathrm{cm} / \mathrm{h})\end{array}$ \\
\hline Glucose & $9.5 \times 10^{-5}$ & 0.29 \\
Urea & $1.2 \times 10^{-4}$ & 0.68 \\
Glycerol & $1.4 \times 10^{-4}$ & 0.41 \\
Thiourea & $9.6 \times 10^{-5}$ & 0.62 \\
\hline
\end{tabular}




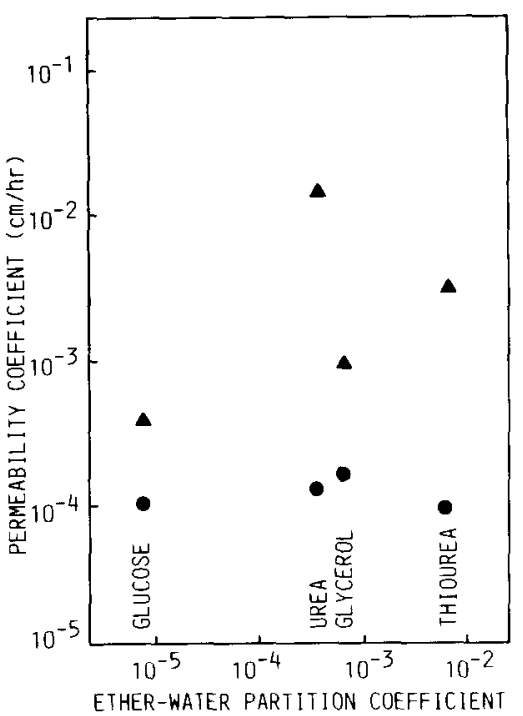

Fig. 2. Permeability coefficients as calculated over the first $6 \mathrm{~h}$ $(\bullet)$ and last $6 \mathrm{~h}$ (A) of a 30-h run for glucose, urea, glycerol and thiourea as functions of the ether-water partition coefficients.

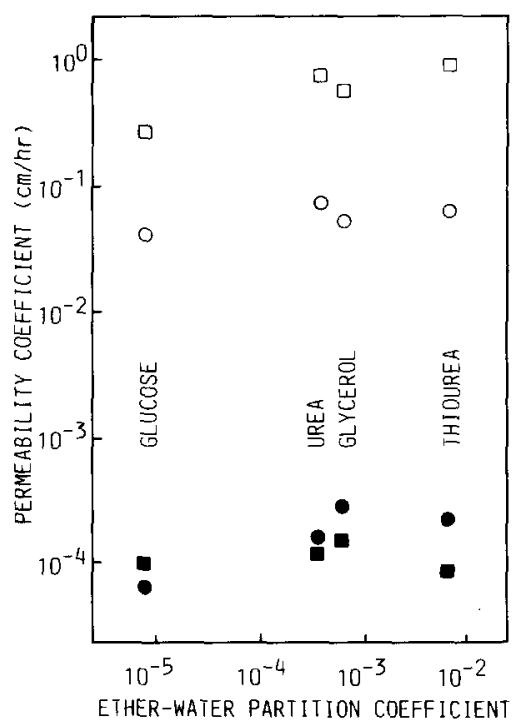

Fig. 3. Permeability coefficients of glucose, urea, glycerol and thiourea for full thickness rabbit skin (๑) (Treherne, 1956); full thickness nude mouse skin (D) (this study); dermis of rabbit (O) (Treherne, 1956); dermis of nude mouse skin ( $\square$ ) (this study); all as a function of the ether-water partition coefficient. the compounds, are presented in Fig. 2 as a function of their ether-water partition coefficients. The smaller increase in permeation of glucose and glycerol than that of urea and thiourea may indicate a difference in diffusion pathways for these compounds. The phenomenon should be studied in conjunction with the physical and chemical changes in skin during permeation studies.

The changing permeability of these compounds with time and especially after $6 \mathrm{~h}$ with regard to the percutaneous absorption of urea is discussed by Ackermann et al. (1985). Physical and chemical deterioration of the barrier phase seem to be responsible for the increase in permeation.

In Fig. 3 the values found in this study and those of Treherne (1956) for full thickness skin and dermis are presented. The initial estimates for this study were those based on the first $6 \mathrm{~h}$ of the experiments. A remarkable similarity is found when the initially estimated permeability coefficients obtained in this study are compared to those obtained by Treherne (1956) for excised rabbit skin. Nude mouse skin and excised rabbit skin seem to have very similar properties to the permeation of these polar compounds.

\section{Conclusion}

The permeability coefficients of urea, thiourea, glycerol and glucose were found to be essentially in the same order $\left(1.0 \times 10^{-4}\right.$ to $\left.1.4 \times 10^{-4} \mathrm{~cm} / \mathrm{h}\right)$ for full thickness nude mouse skin. The etherwater partition coefficients however, ranged between $9.0 \times 10^{-6}$ for glucose to $7.0 \times 10^{-3}$ for thiourea. When permeability is taken as a function of the ether-water partition coefficient, there seems to be no dependence of permeability on the polarity of these compounds. It seems as if the percutaneous absorption of these compounds takes place mainly through hydrophilic and water-filled regions in the skin. According to these results the skin does not act as a simple lipoidal barrier.

A phenomenon of increasing permeation was observed for these compounds over the first $30 \mathrm{~h}$ of an experiment. This phenomenon may be due to hydration or physical or chemical change in the barrier phase of the skin. 


\section{Acknowledgements}

This research was sponsored by the CSIR, Smith \& Nephew, Noristan, Smith, Kline \& French, and The Institute of Industrial Pharmacy and the Department of Pharmaceutics at the Potchefstroom University.

\section{References}

Ackermann, C., The percutaneous absorption of hydrophilic compounds - an in vitro study on hairless mouse skin $\mathrm{Ph} . \mathrm{D}$. Thesis, The Potchefstroom University for Christian Higher Education, 1983.

Ackermann, C., Flynn, G.L. and Van Wyk, C.J., Percutaneous absorption of urea. Int. J. Cosmet. Sci., 7 (1985) 251-264.

Aguiar, A.J. and Weiner, M.A., Percutaneous absorption studies of chloramphenicol solutions. J. Pharm. Sci., 58 (1969) 210-215.
Collander, R., Die Verteilung organischer Verbindungen zwischen Äther und Wasser, Acta Chem. Scand., 3 (1949) 717-747.

Dürrheim, H.H., Flynn, G.L., Higuchi, W.I. and Behl, C.H., Permeation of hairless mouse skin. I. Experimental methods and comparison with human epidermal permeation by alkanols. J. Pharm. Sci., 69 (1980) 781-786.

Flynn, G.L., Topical drug absorption and topical pharmaceutical systems. In G.S. Banker and D.T. Rhodes (Eds.), Modern Pharmaceutics, Marcel Dekker, New York, 1979, pp. 263-328.

Ross, E.J., The transfer of non-electrolytes across the bloodaqueous barrier. J. Physiol., 112 (1951) 229-237.

Sandell, K.B., Uber das Wasserstoff - Bindungsvermögen und die Struktur von Thioessigsaure und Thioacetamid. Naturwissenschaften, 53 (1966) 330-331.

Smith, W.M., An Inquire into the Mechanism of Percutaneous Absorption of Hydrocortisone and its $21-n-A l k y l$ Esters, Ph.D. Thesis, The University of Michigan, 1982.

Treherne, J.E., The permeability of skin to some non-electrolytes. J. Physiol. (Lond)., 133 (1956) 171-180. 